\title{
TINDAKAN ULTRA VIRES DIREKSI DAN AKIBAT HUKUMNYA BAGI PERSEROAN TERBATAS
}

\author{
Abdul Rokhim \\ Fakultas Hukum Universitas Islam Malang \\ Jl. Mayjen Haryono No. 193, \\ Dinoyo, Kec. Lowokwaru, Kota Malang, Jawa Timur 65144 \\ Email: abdulrokhimsda@gmail.com
}

\begin{abstract}
The Actions of the Board of Directors are legally qualified as the actions of the Company as a legal entity if carried out by the authority and objectives of the Company as stated in the company's articles of association. The actions of directors that are carried out outside the authority or beyond the authority (ultra vires) cannot be qualified as the actions of the company. As a result, such legal action is not binding on the Company and only binds the Board of Directors personally with third parties. The problems examined are the limits of authority of the Board of Directors according to the UUPT and the doctrine and concept of ultra vires directors. Types of normative juridical research with conceptual approach and statute approach. The actions of the board of directors as long as it is carried out within the limits of the authority granted by the law and the articles of association of PT (intra vires) are legally viewed as the actions of PT as a legal entity. Actions of the Board of Directors that are carried out outside the authority or exceed their authority as stipulated in the laws and articles of association of PT (ultra vires) the Board of Directors must be personally responsible with third parties.
\end{abstract}

Keywords: Ultra Vires Action; Board of Directors; Limited Liability Company

\begin{abstract}
ABSTRAK
Tindakan Direksi secara hukum dikualifikasi sebagai tindakan perseroan selaku badan hukum apabila dilakukan sesuai dengan kewenangan dan tujuan perseroan sebagaimana tercantum dalam anggaran dasar perseroan. Tindakan direksi yang dilakukan di luar kewenangan atau melampaui kewenangan (ultra vires) tidak dapat dikualifikasi sebagai tindakan perseroan. Akibatnya, tindakan hukum tersebut tidak mengikat perseroan dan hanya mengikat Direksi secara pribadi dengan pihak ketiga. Permasalahan yang diteliti yaitu batas-batas kewenangan Direksi menurut UUPT dan doktrin dan konsep ultra vires direksi. Jenis penelitian yuridis normatif dengan pendekatan konsep (conceptual approach) dan pendekatan peraturan perundangundangan (statute approach). Tindakan direksi sepanjang dilakukan dalam batas-batas kewenangan yang diberikan oleh undang-undang dan anggaran dasar PT (intra vires) secara hukum dipandang sebagai tindakan PT selaku badan hukum. Tindakan Direksi yang dilakukan di luar kewenangan atau melampaui kewenangannya sebagaimana diatur dalam undang-undang dan anggaran dasar PT (ultra vires) Direksi harus bertanggung jawab secara pribadi dengan pihak ketiga.
\end{abstract}

Kata Kunci: Tindakan Ultra Vires; Direksi; Perseroan Terbatas

\section{PENDAHULUAN}

Perseroan Terbatas (PT), selanjutnya dapat disebut perseroan, menurut Pasal 1 angka 1 Undang-undang Nomor 40 Tahun 2007 tentang Perseroan Terbatas (UUPT), adalah badan hukum yang merupakan persekutuan modal, didirikan berdasarkan perjanjian, melakukan kegiatan usaha dengan modal dasar yang seluruhnya terbagi dalam saham dan memenuhi 
persyaratan yang ditetapkan dalam kewenangan organ PT itu didistribusikan undang-undang ini serta peraturan kepada RUPS, Direksi, dan Dewan pelaksanaannya. Komisaris.

PT sebagai suatu badan hukum,

Dengan demikian, apabila suatu menurut Pasal 1 angka 2 UUPT, memiliki organ perseroan yang dinamakan Rapat Umum Pemegang Saham, Direksi, dan Dewan Komisaris. Rapat Umum Pemegang Saham (RUPS) adalah organ perseroan yang mempunyai wewenang yang tidak diberikan kepada Direksi atau Dewan Komisaris dalam batas yang ditentukan dalam undang-undang ini dan/atau anggaran dasar (Pasal 1 angka 4 UUPT).

Direksi adalah organ perseroan yang berwenang dan bertanggung jawab penuh atas pengurusan perseroan untuk kepentingan perseroan, sesuai dengan maksud dan tujuan perseroan serta mewakili perseroan, baik di dalam maupun di luar pengadilan sesuai dengan ketentuan anggaran dasar (Pasal 1 angka 5 UUPT).

Dewan Komisaris adalah organ perseroan yang bertugas melakukan pengawasan secara umum dan/atau khusus sesuai dengan anggaran dasar serta memberi nasihat kepada Direksi (Pasal 1 angka 6 UUPT).

Berdasarkan ketentuan di atas, UUPT menganut prinsip distribution of power (pembagian kekuasaan), artinya kewenangan telah dialokasikan kepada Direksi atau Dewan Komisaris, maka RUPS menjadi tidak berwenang terhadap hal itu. Namun demikian, sebagai pemegang kekuasaan tertinggi menurut visi UUPT, kekuasaan RUPS juga merupakan kekuasaan sisa (residual power), dalam arti apabila ada kekuasaan yang tidak termasuk ke dalam kewenangan Direksi atau Dewan Komisaris, dan tidak tegas pula disebut kewenangan RUPS, maka kekuasaan tersebut menjadi kewenangan RUPS.

Dengan demikian, terhadap kekuasaan Direksi dan Dewan Komisaris, UUPT menganut doktrin limitative power (pembatasan kekuasaan), yang berarti pada prinsipnya mereka hanya mempunyai kewenangan sejauh yang diberikan oleh undang-undang dan atau anggaran dasar, ${ }^{1}$ sedang sisanya merupakan kewenangan RUPS.

Tulisan ini memfokuskan kajiannya pada kewenangan Direksi dalam melakukan tindakan pengurusan perseroan sebagaimana dimaksud dalam Pasal 1 angka 5 UUPT dan Pasal 92 ayat (1) UUPT, yang menyatakan bahwa Direksi

1 Munir Fuady, (1996), Hukum Bisnis Dalam Teori dan Praktek, Buku Ketiga, cet. I,Bandung; Citra Aditya Bakti. Hlm. 25-26. 
menjalankan pengurusan perseroan untuk kepentingan perseroan dan sesuai dengan maksud dan tujuan perseroan. Di samping memiliki kewenangan untuk melakukan tindakan pengurusan, Direksi juga memiliki kewenangan untuk mewakili perseroan baik di dalam maupun di luar pengadilan (Pasal 98 ayat (1) UUPT).

Pengurusan (manajemen) perseroan, menurut Victor Fungkong, pada prinsipnya berarti: (1) mengerjakan segala sesuatu yang harus dikerjakan demi tercapai-nya maksud dan tujuan perseroan; (2) mengerjakan segala sesuatu yang ditentukan dalam akta pendirian atau anggaran dasar perseroan; (3) mengerjakan segala sesuatu yang diharuskan oleh hukum; dan (4) melaksanakan kebijaksanaan perseroan yang ditentukan oleh RUPS. ${ }^{2}$

Sedangkan, menjalankan perwakilan, menurut Rudhi Prasetya, berarti "mewakili perseroan dalam segala tindakan,, 3 yang menurut undang-undang dapat dilakukan baik di dalam maupun di luar pengadilan. Kewenangan Direksi untuk mewakili perseroan itu sifatnya tidak terbatas dan tidak bersyarat, kecuali ditentukan lain dalam UUPT, anggaran dasar, atau keputusan RUPS (Pasal 98 ayat (3) UUPT).

Sebagaimana telah ditegaskan dalam Pasal 92 ayat (1) UUPT, Direksi menjalankan pengurusan Perseroan untuk kepentingan perseroan dan sesuai dengan maksud dan tujuan Perseroan. Tujuan perseroan ini tentu seperti yang tercantum dalam anggaran dasarnya.

Persoalannya adalah UUPT tidak menyebutkan secara tegas apa akibat hukumnya jika ketentuan dalam anggaran dasar disimpangi oleh Direksi atau Direksi melakukan tindakan di luar batas kewenangannya (ultra vires). Dalam hal ini, apakah tidakan Direksi tersebut dapat dikualifikasi tindakan perseroan, sehingga akibatnya menjadi tanggung jawab perseroan?

Berdasarkan latar belakang masalah di atas, isu hukum yang akan diteliti dan dianalisis dalam tulisan ini adalah tentang: (a) batas-batas kewenangan Direksi menurut UUPT dan doktrin; (b) konsep ultra vires direksi dan akibat hukumnya bagi Perseroan Terbatas (PT).

Penelitian ini bertujuan untuk menganalisis pokok masalah berdasarkan peraturan perundang-undangan dan anggaran dasar perseroan berkaitan dengan

2 Victor Fungkong, (20-21 Juni 1989), Hukum Perusahaan dan Bentuk-bantuk Perusahaan, Makalah, Jakarta; Konferensi tentang Direktur Perusahaan di Indonesia, Centre for Management Technology. Hlm. 11-12.

3 Rudhi Prasetya, (1996), Kedudukan Mandiri Perseroan Terbatas, Bandung; Citra Aditya Bakti. Hlm. 19. 
tindakan direksi dan akibat hukumnya bagi perseroan. Oleh karena itu, penelitian ini termasuk jenis penelitian hukum normatif, yang menggunakan pendekatan konsep (conceptual approach) dan pendekatan peraturan perundang-undangan (statute approach).

Penelitian ini menggunakan data sekunder berupa bahan hukum primer (peraturan perundang-undangan) dan bahan hukum sekunder (dokumen dan bahan pustaka) yang digunakan untuk analisis terhadap peraturan perundangundangan dimaksud. ${ }^{4}$ Bahan-bahan hukum tersebut setelah dikumpulkan dan diklasifikasi, kemudian dianalisis secara kualitatif dengan menggunakan metode penafsiran hukum.

\section{PEMBAHASAN}

\section{Batas Kewenangan Direksi Menurut UUPT dan Doktrin}

Direksi sebagai salah satu organ PT mempunyai kewenangan untuk melakukan tindakan-tindakan dalam rangka mencapai tujuan PT. Kewenangan ini, menurut Sumantoro, dapat mencakup hal-hal yang secara tegas dinyatakan (express powers) dan hal-hal yang tidak secara tegas dinyatakan (implied powers). ${ }^{5}$
Dalam kenyataannya, kewenangan yang secara tegas dinyatakan, umumnya dirumuskan di dalam anggaran dasar suatu PT. Dengan demikian, kewenangan direksi suatu PT sangat tergantung kepada tujuan dan bidang usaha PT, serta perumusannya di dalam anggaran dasar PT itu sendiri. Sedang, kewenangan yang tidak secara tegas dinyatakan dapat mencakup tindakan-tindakan yang dianggap perlu untuk mencapai tujuan PT dan tidak bertentangan dengan ketentuan-ketentuan yang berlaku.

Mengenai ruang lingkup dan kriterianya, dapat diserahkan pada dunia praktik sesuai dengan etika bisnis dan perkembangan dunia usaha. ${ }^{6}$ Persoalannya adalah dari mana Direksi suatu PT memperoleh wewenang dan bagaimana batas-batas kewenangannya itu?

Secara umum, kewenangan direksi bersumber dari ketentuan undang-undang dan anggaran dasar PT yang bersangkutan. $^{7} \quad$ Tentang bagaimana wewenang Direksi dapat dibatasi dalam anggaran dasar, UUPT tidak mengaturnya.

Dalam hubungan ini, Rudhi Prasetya berpendapat bahwa dengan tidak mengurangi apa yang telah berjalan selama

4 Menurut Ronny Hanitijo Soemitro, (1994),Metodologi Penelitian Hukum dan Jurimetri, Cet. V, Jakarta; Ghalia Indonesia, Hlm. 11-12, "Penelitian hukum normatif disebut juga penelitian hukum kepustakaan, karena hanya dilakukan dengan cara meneliti bahan pustaka".

5 Sumantoro, (1986), Hukum Ekonomi, cet. I, Jakarta; Universitas Indonesia Press. Hlm. 289-290.

6 Ibid.

7 Victor Fungkong, Op. Cit. Hlm. 2. 
ini, di dalam anggaran dasar selalu dapat ditentukan perbuatan-perbuatan yang diperkecualikan yang terlebih dahulu harus disetujui oleh RUPS atau Dewan Komisaris dengan memperhatikan ketentuan UUPT. $^{8}$ Misalnya, menurut Pasal 102 ayat (1) UUPT, Direksi wajib meminta persetujuan RUPS untuk: (a) mengalihkan kekayaan Perseroan; atau (b) menjadikan jaminan utang kekayaan Perseroan.

Menurut ajaran (doktrin), tindakan pengurusan atau manajemen suatu PT selalu dilakukan oleh suatu organ yang dinamakan "direksi" atau "direktur". Direktur, menurut Geoffrey Morse, mempunyai wewenang untuk mengurus perusahaan dan menjalankan semua kekuasaan perusahaan (the business of the company shall be managed by the directors who may exercise all the powers of the company). ${ }^{9}$

Tindakan menjalankan pengurusan (dalam arti luas), menurut Rudhi Prasetya, dibedakan menjadi dua macam, yaitu: (1) menjalankan pekerjaan pengurusan (daden van beheer); dan (2) menjalankan pekerjaan "kepemilikan" atau "penguasaan" (daden van eigendom atau daden van beschikking). Perbuatan pengurusan dalam arti sempit (daden van beheer) adalah tindakan yang dilakukan sehari-hari dalam hubungannya dengan tujuan perseroan yang bersangkutan.

Sedangkan, perbuatan "kepemilikan" atau "penguasaan" adalah tindakan yang secara tidak langsung menyangkut bidang usaha yang menjadi tujuan dari perseroan. ${ }^{10}$

Menurut Achmad Ichsan sebagaimana dikutip oleh Yahya Harahap mengartikan pengurusan (beheren) sebagai tugas atau fungsi Direksi untuk melaksanakan kekuasaan administrasi, sedangkan beschikking diartikan sebagai tugas atau fungsi Direksi untuk memelihara harta kekayaan perseroan. ${ }^{11}$

Peran direksi terhadap perseroan sangat besar, karena yang membuat perseroan tetap eksis, berkembang, dan menjadi besar bukanlah RUPS atau komisaris, melainkan direksi.

Betapapun lengkap dan bagusnya keputusan RUPS, hal itu tidak ada artinya, apabila Direksi tidak mampu menerapkannya dengan baik untuk kepentingan perseroan. Oleh karena begitu besarnya peran Direksi, agar tidak terjadi penyalahgunaan kekuasaan, maka perlu

Rudhi Prasetya, Op. Cit. Hlm. 215.

Geoffrey Morse, (1987), Charlesworth's Company Law, London; ELBS ed. Hlm. 373.

Rudhi Prasetya, Op. Cit. Hlm. 210-211.

M. Yahya Harahap, (2016), Hukum Perseroan Terbatas, Jakarta; Sinar Grafika, Hlm. 346. 
diatur secara tegas mengenai kewajiban dan "hak-hak" Direksi. ${ }^{12}$

Terkait dengan kewajiban direksi, secara garis besar ada dua macam kewajiban Direksi, yaitu: (1) kewajiban Direksi yang berkaitan dengan perseroan; dan (2) kewajiban Direksi yang berkaitan dengan RUPS. Menurut ketentuan Pasal 100 ayat (1) UUPT, Direksi wajib:

a. membuat daftar pemegang saham, daftar khusus, risalah RUPS, dan risalah rapat Direksi;

b. membuat laporan tahunan sebagaimana dimaksud dalam Pasal 66 UUPT dan dokumen keuangan Perseroan sebagaimana dimaksud dalam Undang-Undang tentang Dokumen Perusahaan; dan

c. memelihara seluruh daftar, risalah, dan dokumen keuangan Perseroan sebagaimana dimaksud pada huruf a dan huruf $b$ dan dokumen Perseroan lainnya.

Selanjutnya, Pasal 101 ayat (1) UUPT menyebutkan bahwa anggota Direksi wajib melaporkan kepada Perseroan mengenai saham yang dimiliki anggota Direksi yang bersangkutan dan/atau keluarganya dalam Perseroan dan Perseroan lain untuk selanjutnya dicatat dalam daftar khusus.

Bagi anggota Direksi yang tidak melaksanakan kewajiban sebagaimana dimaksud pada ayat (1) dan menimbulkan kerugian bagi Perseroan, maka menurut Pasal 101 ayat (2) bertanggung jawab secara pribadi atas kerugian Perseroan tersebut.

Di samping memiliki kewajiban, Direksi juga mempunyai hak (baca: kewenangan), yaitu: (1) untuk dan atas nama perseroan mewakili perseroan baik di dalam maupun di luar pengadilan; (2) memberikan kuasa tertulis kepada seorang atau lebih karyawan perseroan atau orang lain untuk dan atas nama perseroan melakukan tindakan hukum tertentu seperti tertuang dalam surat kuasa tersebut; (3) mengajukan usul kepada Pengadilan Negeri agar perseroan dinyatakan pailit setelah terlebih dahulu disetujui oleh RUPS; (4) hak untuk membela diri dalam forum RUPS jika Direksi telah diberhentikan untuk sementara waktu oleh RUPS atau komisaris; dan (5) hak untuk mendapatkan gaji, tantieme dan tunjangantunjangan lain sesuai dengan akta pendirian atau anggaran dasar.

Mengenai kewenangan Direksi untuk mewakili perseroan, pasal 98 ayat (2) UUPT menjelaskan, dalam hal anggota Direksi terdiri lebih dari 1 (satu) orang, yang berwenang mewakili Perseroan adalah setiap anggota Direksi, kecuali ditentukan lain dalam anggaran dasar. Dengan demikian, UUPT menganut sistem perwakilan kolegial. Artinya, masingmasing anggota Direksi mempunyai

\footnotetext{
12 Anisitus Amanat, (1996), Pembahasan Undang-undang Perseroan Terbatas 1995 dan Penerapannya dalam Akta Notaris, cet. I, Jakarta; RajaGrafindo Persada, Hlm. 128.
} 
kewenangan untuk mewakili perseroan. Meskipun, misalnya secara intern ada pembagian tugas di antara para anggota Direksi, pembagian tugas ini tidak berlaku (mengikat) secara ektern kepada pihak ketiga. $^{13}$

Dengan demikian, PT tidak dapat menolak tanggungjawab manakala ada anggota Direksi yang bertindak melampaui batas pembagian tugas yang ditentukan di antara mereka. Hal ini, menurut Rudhi Prasetya, menunjukkan bahwa kedudukan di antara anggota Direksi itu sederajat. Kedudukan Direktur Utama (Presiden Direktur), menurut sistemnya, tidak lebih tinggi daripada anggota Direksi yang lain. $^{14}$

Kendatipun UUPT menganut sistem perwakilan kolegial, namun untuk kepentingan praktis, masing-masing anggota Direksi berwenang mewakili perseroan, kecuali ditentukan lain dalam Anggaran Dasar PT.

Bentuk perwakilan pada badan hukum itu merupakan suatu perwakilan khusus yang ditetapkan dalam anggaran dasar atau peraturan-peraturan lain dari badan hukum itu. Oleh karena kedudukan Direksi sebagai wakil dari $\mathrm{PT},{ }^{15}$ maka segala tindakan direksi dalam batas-batas kekuasaan yang diberikan oleh undangundang dan atau anggaran dasar dipandang sebagai tindakan PT. Bentuk perwakilan yang demikian ini, menurut Paul Scholten, termasuk dalam golongan aanstelling (pengangkatan). ${ }^{16}$ Persoalannya adalah bagaimana jika Direksi melanggar batasbatas kekuasaannya? Dalam kepustakaan, umumnya hal itu dinamakan tindakan ultra vires.

\section{Konsep Ultra Vires Direksi dan Akibat Hukumnya Bagi PT}

Istilah ultra vires dalam bahasa Latin, berarti "di luar" atau "melebihi" kekuasaan (outside the power), yaitu kekuasaan yang diberikan hukum terhadap suatu badan hukum (dalam hal ini Perseroan Terbatas yang diwakili oleh Direksi). Istilah lain yang seringkali digunakan untuk mendefinisikan ultra vires adalah "pelampauan wewenang". 17

Ultra vires diterapkan dalam arti luas yakni tidak hanya kegiatan yang dilarang oleh Anggaran Dasar suatu PT, tetapi

13 Arifin Kadarisman, (20-21 Juni 1989), Direksi sebagai Pekerja pada Perseroan Terbatas, Makalah, Jakarta; Konferensi tentang Direktur Perusahaan di Indonesia, Centre for Management Technology. Hlm. 5-6.

14 Rudhi Prasetya, Op. Cit. Hlm. 26.

15 Direksi mewakili PT baik di dalam maupun di luar pengadilan. Dalam melaksanakan tugas ini status hukum direksi adalah sebagai penerima kuasa (lasthebber) dari PT. Dalam hubungan ini, berlaku ketentuan Pasal 1792 s.d. 1799 KUHPerdata.

16 Ali Rido, (1986), Badan Hukum dan Kedudukan Badan Hukum Perseroan, Perkumpulan, Koperasi, Yayasan, Wakaf, cet. IV, Bandung; Alumni, Hlm. 19.

17 Munir Fuadi, (2010), Doktrin-Doktrin dalam Corporate Law dan Eksistensinya dalam Hukum Indonesia, Bandung; Citra Aditya Bakti. Hlm. 102. 
termasuk juga tindakan yang tidak dilarang, tetapi melampaui kewenangan yang diberikan. Doktrin ultra vires memiliki basis teori keagenan atau teori pemberian kuasa.

Konstruksi hubungan hukum terjadi antara pihak pemberi kuasa (principal) pada satu sisi dan penerima kuasa (agent) pada sisi lain. Dalam hal ini, Direksi selaku organ perseroan merupakan agent dan perseroan merupakan principal-nya. Agent harus melakukan tindakan dalam batasbatas kewenangan (intra vires) yang diberikan oleh principal sebagaimana yang ditentukan dalam anggaran dasar perseroan. Apabila Direksi bertindak di luar batas-batas kewenangannya maka organ perseroan tersebut dikategorikan melakukan tindakan ultra vires.

Secara eksplisit tidak ada pengaturan mengenai tindakan ultra vires Direksi dalam UUPT. Namun demikian, secara implisit tindakan ultra vires Direksi PT dapat ditafsirkan secara a contrario berdasarkan ketentuan Pasal 92 ayat (1) dan (2) UUPT.

Pasal 92 ayat (1) UUPT menjelaskan bahwa Direksi menjalankan pengurusan Perseroan untuk kepentingan Perseroan dan sesuai dengan maksud dan tujuan Perseroan. Doktrin ultra vires dalam UUPT dapat ditemukan dalam Pasal 92 ayat (2) UUPT yang menjelaskan bahwa: Direksi berwenang menjalankan pengu- rusan sebagaimana dimaksud dalam ayat (1) sesuai dengan kebijakan yang dipandang tepat, dalam batas yang ditentukan dalam Undang-Undang ini dan/atau anggaran dasar.

Dengan demikian dapat disimpulkan bahwa ultra vires itu adalah tindakan Direksi di luar maksud dan tujuan serta kegiatan usaha Perseroan yang ditentukan dalam undang-undang (khususnya UUPT) dan Anggaran Dasar.

Parafrase "dalam batas yang ditentukan dalam Undang-Undang ini dan/atau Anggaran Dasar" tersirat adanya larangan untuk melakukan tindakan di luar batas yang ditentukan dalam UUPT dan/atau Anggaran Dasar Perseroan, sehingga Anggaran Dasar Perseroan merupakan sumber sekaligus batas kewenangan yang paling utama untuk mengukur terlampauinya kewenangan atau tidak.

Batas tanggung jawab organ Perseroan tercantum dalam beberapa sumber kewenangan, yakni UU, Anggaran Dasar, Putusan RUPS, dan Best Practises (praktik-praktik yang dilakukan oleh organ perseroan, khususnya Direksi, untuk kepentingan terbaik bagi perseroan).

Pasal 1 angka (5) UUPT menegaskan bahwa direksi adalah organ yang bertanggung jawab penuh terhadap kepengurusan sesuai dengan maksud dan tujuan dan berwenang mewakili perseroan, baik di 
dalam maupun diluar, sesuai dengan ketentuan Anggaran Dasar. Berdasar ketentuan ini, maka direksi memiliki dua fungsi yaitu fungsi manajemen ke dalam perseroan dan fungsi kedua representasi ke luar dengan pihak ketiga. Direksi dalam menjalankan kedua fungsi itu harus berpegang kepada maksud dan tujuan sebagai dasar bekerjanya perseroan. Direksi yang bertindak tidak sejalan dengan maksud dan tujuan perseroan dikategorisasikan telah melampaui batas kewenangan atau yang doktrin dikenal sebagai tindakan ultra vires.

Dalam hubungannya dengan perseroan (corporation), "ultra vires", menurut Henry Campbell Black, adalah suatu tindakan yang dilakukan tanpa kewenangan atau di luar ruang lingkup kekuasaan yang ditentukan oleh statuta (anggaran dasar) atau peraturan perundang-undangan di bidang perseroan (an act performed without any authority to act on subject. Acts beyond the scope of the powers of a corporation, as difined by its charter or laws of state of incorporation $)^{18}$

Terdapat tiga kriteria untuk menentukan bahwa tindakan direksi itu termasuk di luar maksud dan tujuan perseroan atau tidak, yaitu apabila terpenuhi salah satu atau krieria di bawah ini: pertama, perbuatan hukum direksi yang bersangkutan secara tegas-tegas dilarang oleh anggaran dasar perseroan. Kedua, dengan memperhatikan keadaan-keadaan khusus, maka perbuatan hukum direksi yang bersangkutan tidak dapat dikatakan akan menunj ang kegiatan-kegiatan yang disebut dalam anggaran dasar perseroan. Ketiga, dengan memperhatikan keadaan-keadaan khusus, maka perbuatan direksi itu tidak dapat diartikan sebagai menunjang kepada kepentingan persero-an. ${ }^{19}$ Dengan demikian koridor yang dapat dipergunakan direksi di dalam mencegah pelanggaran ultra vires adalah dengan selalu berpegang dan bertindak atas nama dan untuk kepentingan perseroan dalam batas-batas yang diizinkan oleh peraturan perundangundangan, khususnya maksud dan tujuan anggaran dasar perseroan.

Pasal 2 UUPT menegaskan bahwa Perseroan harus mempunyai maksud dan tujuan serta kegiatan usaha yang tidak bertentangan dengan ketentuan peraturan perundang-undangan, ketertiban umum, dan/atau kesusilaan. Maksud dan tujuan serta kegiatan usaha tersebut, menurut Pasal 15 ayat (1) huruf b UUPT wajib dimuat dalam Anggaran Dasar dari

18 Henry Campbell Black, (1990), Black's Law Dictionary, 6th ed., St. Paul - Minnesota; West Publishing Co. Hlm. 1522.

19 Agus Riyanto, (_ _ Desember 2016), Ultra Vires dan Kewenangan Direksi, Diakses pada 19 Februari 2019, Dari Binus University Faculty of Humanity: http://business-law.binus.ac.id/2016/12/28/ultravires-dan-kewenangan-direksi/. 
Perseroan. Menurut Yahya Harahap, tindakan Direksi yang tidak sesuai dengan maksud dan tujuan serta kegiatan usaha adalah tindakan di luar kekuasaannya (beyond the power). ${ }^{20}$

Tindakan ultra vires, menurut David Foulkes, tidak hanya mengenai tindakan yang dilakukan oleh orang atau badan yang tidak ditunjuk untuk itu (an act ultra vires is where the person or body doing it has not been properly appointed or constituted), melainkan termasuk pula tindakan yang dilakukan oleh orang yang berwenang, apabila ia telah melampaui wewenang yang diberikan kepadanya (an act will be ultra vires even if done by the proper person properly appointed if he exceeds the power given him). ${ }^{21}$

Doktrin ultra vires, menurut L.B. Curzon, secara efektif membebaskan hubungan (tanggung jawab) perusahaan terhadap pihak ketiga (The ultra vires doctrine was effectively abolished in relation to the company and the third person). ${ }^{22}$ Dalam arti, akibat dari tindakan direksi yang melampaui batas-batas kewenangannya (ultra vires) itu tidak mengikat perseroan yang diwakilinya, melainkan hanya mengikat dan menjadi tanggung jawab direksi secara pribadi dengan pihak ketiga.

Direksi, menurut Geoffrey Morse, merupakan human instrument perseroan. ${ }^{23}$ Oleh karena itu, selama Direksi dalam bertindak ke luar atau terhadap pihak ketiga dilakukan untuk dan atas nama (on behalf of) PT, tidak melampaui batas-batas kekuasaan atau kewenangannya, dan tidak bertentangan dengan maksud dan tujuan PT, ${ }^{24}$ maka Direksi secara hukum tidak terikat secara pribadi atas tindakan yang dilakukannya itu. Dalam hal demikian, PT selaku badan hukum terikat oleh tindakan Direksi. Akan tetapi, jika tindakan Direksi melampaui batas kekuasaannya (ultra vires) atau bertentangan dengan anggaran dasar PT, maka secara hukum hal itu dipandang sebagai tindakan pribadi Direksi, bukan tindakan perseroan. Dalam hal demikian, maka Direksi secara pribadi bertanggungjawab renteng dan sepenuhnya terhadap kerugian yang diderita oleh perseroan dan pihak ketiga.

20 M. Yahya Harahap, Op. Cit. Hlm. 66.

21 David Foulkes, (1976), Introduction to Administrative Law, 4th ed., London; Butterworths. Hlm. 137151.

22 L.B. Curzon, (1993), Dictionary of Law, 4th ed., London; Pitman Publishing. Hlm. 392.

23 Hal ini sesuai dengan pendapat Geoffrey Morse, Op. Cit. Hlm. 338: "As a company has no physical but only a legal existence, the management of its affair is entrusted to human intruments called directors whose exact position in relation to the company ....".

24 Fred B.G. Tumbuan, (dalam Victor Fungkong, Op. Cit. Hlm. 13), mengatakan bahwa suatu tindakan yang secara tegas ditentukan dalam akte pendirian sebagai berada di luar maksud dan tujuan perseroan, maka tindakan ini merupakan ultra vires. 
Ultra vires dapat terjadi karena Direksi melakukan tindakan yang melampaui kekuasaan atau kewenangannya sebagaimana diatur dalam anggaran dasar Perseroan dengan cara mencari atau memanfaatkan kesempatan untuk melakukan tindakan yang menguntungkan pribadi atau orang lain (vested interest), tetapi juga bisa terjadi karena kelalaian "menafsirkan" isi anggaran dasar dan Business Guideline Objective (BGO) berupa kebijakan (policy) PT yang berpedoman kepada anggaran dasar. ${ }^{25}$

Mengacu pada definisi tersebut di atas, doktrin ultra vires dihubungkan dengan Perseroan merupakan permasalahan yang menyangkut dengan transaksi atau kontrak yang dilakukan Direksi dengan pihak ketiga.

Dalam Black's Law Dictionary disebutkan bahwa "By doctrine of ultra vires a contract made by a corporation beyond the scope of its corporate powers its unlawful". ${ }^{26}$

Oleh karena itu, pada dasarnya kontrak atau transaksi yang mengandung ultra vires adalah melanggar hukum (unlawful) atau batal (nullity), akibatnya: ${ }^{27}$ a. Perseroan dapat menolak untuk memenuhi kontrak atau transaksi yang mengandung ultra vires;

b. Meskipun pihak ketiga melakukan kontrak atau transaksi dengan itikat baik (good faith), hal itu belum mencukupi, karena untuk melindungi pihak ketiga atas kontrak atau transaksi yang mengandung ultra vires, pihak ketiga itu harus melihat secara konstruktif maksud dan tujuan atau kapasitas Perseroan yang tercantum dalam Anggaran Dasar.

Dengan demikian, suatu kontrak yang dibuat oleh seorang direktur di luar ruang lingkup kekuasaannya (ultra vires), maka kontrak tersebut dinyatakan melanggar hukum (unlawful), dalam arti kontrak tersebut tidak mengikat perseroan, akan tetapi hanya mengikat direktur tersebut secara pribadi dengan pihak ketiga.

Sehubungan dengan kontrak yang bersifat unlawful, lebih jauh Anderson dan Kumpf menyatakan: “...no act of a corporation and no confeyance or transfer of real or personal property to or by a corporation shall be invalid by reason of the fact that the corporation was without capacity or power to do such an act or to

25 Rudi Agustian Hassim, (23 April 2018), Ultra Vires dan Intra Vires dalam Undang-Undang Perseroan Terbatas Indonesia, Diakses pada tanggal 19 Februari 2019, Dari Rah Law Firm: http://www.rahlawfirm.com/ultra-vires-dan-intra-vires/.

26 Henry Campbell Black, Loc. Cit.

27 M. Yahya Harahap, Op. Cit. Hlm. 66. 
make or receive such a conveyance or transfer...". 28

Dalam UUPT tidak ada pasal-pasal yang mengatur secara tegas mengenai berlakunya doktrin ultra vires. Namun demikian, ada beberapa ukuran yang dapat dijadikan pedoman untuk menentukan apakah suatu tindakan itu termasuk tindakan ultra vires atau intra vires, antara lain dengan melihat pada maksud dan tujuan perseroan yang bersangkutan. Dalam hubungan ini, Fred B.G. Tumbuan menyatakan:

a. Apabila suatu tindakan secara tegas ditentukan dalam akte pendirian perseroan bersangkutan dinyatakan termasuk dalam maksud dan tujuan perseroan, maka tindakan ini bukan merupakan tindakan ultra vires;

b. Apabila suatu tindakan secara tegas ditentukan dalam akte pendirian sebagai berada diluar maksud dan tujuan perseroan, maka tindakan tersebut merupakan tindakan ultra vires;

c. Apabila makna kata-kata yang dipergunakan untuk menjelaskan mengenai maksud dan tujuan perseroan memerlukan penafsiran, maka kata-kata tersebut harus ditafsirkan secara sebagaimana adanya. $^{29}$

Meskipun UUPT tidak mengatur secara tegas mengenai doktrin ultra vires, namun berdasarkan yurisprudensi putusan Mahkamah Agung Republik Indonesia No. 3264.K/Pdt/1992, tertanggal 28 Agustus 1996, dalam perkara utang piutang antara PT Oesaha Sandang Batoenoenggal (penggugat/pemohon kasasi) melawan PT Dhaseng Ltd. dan PT Interland Indonesia Ltd. (masing-masing sebagai tergugat/ termohon kasasi I dan II) serta Mediarto Prawiro (direktur dari kedua PT yang disebut terakhir dan sekaligus sebagai tergugat/termohon kasasi III), hakim telah menggunakan doktrin ultra vires sebagai salah satu pertimbangan hukum (ratio decidendi) dalam memutuskan perkara tersebut.

Dalam putusan tersebut, tindakan Mediarto Prawiro (selaku direktur utama dari PT Dhaseng Ltd. dan PT Interland Indonesia Ltd.) dalam bentuk pembebanan atau pengakuan utang kepada PT Oesaha Sandang Batoenoenggal, meski hal itu dilakukan untuk dan atas nama kedua PT tersebut, akan tetapi karena perbuatan itu

28 Ronald A. Anderson dan Walter A. Kumpf, (1972), Business Law, 6th ed., Cincinnati, Ohio; SouthWestern Publishing Co. Hlm. 712-713.

29 Victor Fungkong, Op. Cit. Hlm. 13. Perkataan "harus ditafsirkan secara sebagaimana adanya" harus diartikan sebagaimana lazimnya kata-kata tersebut digunakan oleh setiap orang dalam mengurus perseroan sesuai dengan maksud dan tujuannya dalam anggaran dasar, bukan semata-mata menurut maksud dari para pendiri (promotors) perseroan. 
dilakukan tanpa persetujuan tertulis dari salah seorang komisaris sebagaimana yang disyaratkan oleh Pasal 11 ayat (2) Anggaran Dasar tergugat I dan II, maka oleh hakim hal itu dipandang sebagai tindakan yang bersifat ultra vires, karena tindakan itu sudah berada di luar batas kewenangannya. Oleh karena itu, tindakan tergugat III tersebut tidak sah (unlawful) dan tidak mengikat kepada tergugat I dan tergugat II sesuai dengan asas pertanggungjawaban terbatas (limited lialibity) yang melekat pada tergugat I dan II sebagai badan hukum. Ini berarti, utangutang yang dibuat oleh tergugat III (Mediarto Prawiro) yang dilakukan tanpa persetujuan komisaris dari tergugat I dan tergugat II sepenuhnya adalah tanggung jawab pribadi tergugat III untuk membayarnya kepada penggugat (PT Oesaha Sandang Batoenoenggal). ${ }^{30}$ Dengan demikian, penerapan doktrin ultra vires ini diharapkan dapat mencegah atau menanggulangi terjadinya penyalahgunaan wewenang oleh direksi terhadap perseroan dan atau pihak ketiga yang beritikad baik.

Jadi, tindakan Direksi dibatasi oleh tujuan Perseroan, kapasitas perseroan mengadakan kontrak atau transaksi maupun sebagai donasi hanya sebatas tujuan yang ditentukan dalam Anggaran
Dasar. Di luar itu, sudah berada di luar kapasitas perseroan. Oleh karena itu, tindakan tersebut dikatagorikan sebagai ultra vires dan batal karena hukum (null and void; nietig van rechtswege). Sehubungan dengan itu, sesuai dengan doktrin ultra vires: $:^{31}$

a. Perseroan tidak dapat dituntut atas kontrak atau transaksi yang ultra vires;

b. Perseroan juga tidak dapat mengukuhkan dan melaksanakannya;

c. Rapat Umum Pemegang Saham (RUPS) tidak dapat mengesahkan atau menyetujui tindakan Direksi yang mengandung ultra vires.

Terkait dengan tanggung jawab Direksi dalam menjalankan tugas pengurusan Perseroan sesuai dengan maksud dan tujuan Perseroan yang terdapat dalam Pasal 92 ayat (1) UUPT, Pasal 97 ayat (1), (2), dan (3) UUPT menyebutkan:

1. Direksi bertanggung jawab atas pengurusan Perseroan sebagaimana dimaksud dalam Pasal 92 ayat (1).

2. Pengurusan sebagaimana dimaksud pada ayat (1), wajib dilaksanakan setiap anggota Direksi dengan itikad baik dan penuh tanggung jawab.

\footnotetext{
30 Lihat Putusan Mahkamah Agung R.I. No. 3264 K/Pdt/1992, tertanggal 28 Agustus 1996, termuat dalam majalah Varia Peradilan, Th. XIV No. 160, Januari 1999, Hlm. 17-27.

31 Ibid. Hlm. 67
} 
3. Setiap anggota Direksi bertanggung jawab penuh secara pribadiatas kerugian Perseroan apabila yang bersangkutan bersalah atau lalai menjalankan tugasnya sesuai dengan ketentuan sebagaimana dimaksud pada ayat (2).

Di samping itu, direksi juga mempunyai tanggung jawab internal (ke dalam) PT yang diurusnya itu. Tanggung jawab ini terkait dengan penunaian tugas Direksi kepada perseroan.

Dalam hal PT menderita kerugian yang disebabkan oleh kecerobohan atau kurang cermatnya Direksi dalam melakukan tugasnya, seperti kelalaian melakukan kewajiban-kewajiban, kekhilafan yang tidak dapat diampuni, maka menurut Rochmat Soemitro, PT dapat menuntut ganti rugi kepada diri pribadi Direksi yang menyebabkan kerugian itu. Jika hal itu dilakukan oleh lebih dari seorang Direksi, maka tiap-tiap anggota Direksi bertanggungjawab renteng terhadap perseroan, kecuali mereka dapat membuktikan bahwa ia tidak bersalah. ${ }^{32}$

Selanjutnya, terkait kerugian yang dialami oleh perseroan akibat tindakan Direksi yang melakukan ultra vires atau tindakan yang melampaui batas kewenangan dan kapasitas perseroan yang ditentukan dalam Anggaran Dasar, hari. undang-undang memberi hak kepada setiap pemegang saham mengajukan gugatan terhadap perseroan ke Pengadilan Negeri. Hal ini ditegaskan dalam Pasal 61 UUPT yang menyebutkan:

1. Setiap pemegang saham berhak mengajukan gugatan terhadap Perseroan ke pengadilan negeri apabila dirugikan karena tindakan Perseroan yang dianggap tidak adil dan tanpa alasan wajar sebagai akibat keputusan RUPS, Direksi, dan/atau Dewan Komisaris.

2. Gugatan sebagaimana dimaksud pada ayat (1) diajukan ke pengadilan negeri yang daerah hukumnya meliputi tempat kedudukan Perseroan.

Dengan demikian, berarti bahwa jika Direksi mewakili Perseroan baik di dalam maupun di luar pengadilan melakukan perbuatan ultra vires, maka bisa digugat oleh pemegang saham.

Gugatan yang diajukan itu menurut Penjelasan Pasal 61 ayat (1) UUPT, pada dasarnya memuat permohonan agar Perseroan menghentikan tindakan yang merugikan tersebut dan mengambil langkah tertentu baik untuk mengatasi akibat yang sudah timbul maupun untuk mencegah tindakan serupa di kemudian

32 Rochmat Soemitro, (1993), Hukum Perseroan Terbatas, Yayasan dan Wakaf, cet. I, Bandung; Eresco. HIm. 47-48. 
Berdasarkan uraian di atas, maka pada prinsipnya segala tindakan Direksi yang dilakukan secara sah, dalam arti sesuai dengan kewenangannya sesuai UU dan anggaran dasar perseroan, untuk dan atas nama perseroan, bukan untuk kepentingan pribadi, maka tindakan yang demikian itu dikategorikan tindakan intra vires yang secara hukum dikualifikasi sebagai tindakan perseroan.

Oleh karena itu, segala konsekuensi yuridis atas tindakan perseroan itu, baik atau buruk, untung atau rugi, akan dipikul oleh perseroan. Dengan demikian, segala pertanggungjawaban yang timbul dari perbuatan tersebut hanya dapat dibebankan kepada PT itu sendiri selaku badan hukum, terlepas dari tanggung jawab pribadi direksi yang melakukan perbuatan.

Hal ini sesuai dengan karakteristik PT yang kedudukannya mandiri dan pertanggung-jawabannya terbatas. Sebaliknya, tindakan direksi yang melampaui batas kewenangannya (ultra vires) baik menurut UU maupun anggaran dasar PT, maka akibat dari tindakan tersebut secara hukum tidak mengikat PT selaku badan hukum.

Dalam arti, sungguhpun hal itu merupakan tindakan direksi, maka yang harus bertanggungjawab atas tindakan tersebut adalah Direksi secara pribadi, bukan perseroan selaku badan hukum.

\section{KESIMPULAN}

a. Direksi menurut UUPT memiliki dua kewenangan, yakni (1) melakukan tindakan pengurusan sehari-hari perusahaan menurut anggaran dasar dan peraturan perundang-perundangan; (2) mewakili perseroan baik di dalam maupun di luar pengadilan. Oleh karena kedudukan Direksi sebagai wakil dari PT, maka segala tindakan direksi sepanjang dilakukan dalam batas-batas kewenangan yang diberikan oleh undang-undang dan anggaran dasar PT (intra vires) secara hukum dipandang sebagai tindakan PT selaku badan hukum.

b. Tindakan Direksi yang dilakukan di luar kewenangan atau melampaui kewenangannya sebagaimana diatur dalam undang-undang dan anggaran dasar PT (ultra vires) secara hukum tidak dapat dikualifikasi sebagai tindakan perseroan selaku badan hukum. Akibatnya, tindakan tersebut tidak mengikat perseroan sebagai badan hukum, dan oleh karena itu Direksi harus bertanggung jawab secara pribadi dengan pihak ketiga.

\section{DAFTAR PUSTAKA}

Peraturan Perundang-undangan dan Putusan Pengadilan

Undang-Undang Nomor 40 Tahun 2007 tentang Perseroan Terbatas.

Putusan Mahkamah Agung R.I. No. 3264 K/Pdt/1992 tertanggal 28 Agustus 1996. 


\section{Buku}

Ali Rido, (1986), Badan Hukum dan Kedudukan Badan Hukum Perseroan, Perkumpulan, Koperasi, Yayasan, Wakaf, cet. IV, Bandung; Alumni.

Anisitus Amanat, (1996), Pembahasan Undang-undang Perseroan Terbatas 1995 dan Penerapannya dalam Akta Notaris, cet. I, Jakarta; Raja Grafindo Persada.

Curzon, L.B., (1993), Dictionary of Law, 4th ed., London; Pitman Publishing.

David Foulkes, (1976), Introduction to Administrative Law, 4th ed., London; Butterworths.

Geoffrey Morse, (1987), Charlesworth's Company Law, London; ELBS ed.

Henry Cambell Black, (1990), Black's Law Dictionary, 6th ed., St. Paul Minnesota; West Publishing Co.

Munir Fuady, (1996), Hukum Bisnis dalam Teori dan Praktek: Buku Ketiga, Cet. I, Bandung; Citra Aditya Bakti.

, (2010), Doktrin-Doktrin dalam Corporate Law dan Eksistensinya dalam Hukum Indonesia, Bandung; Citra Aditya Bakti.

Rochmat Soemitro, (1993), Hukum Perseroan Terbatas, Yayasan dan Wakaf, cet. I, Bandung; Eresco.

Ronald A. Anderson dan Walter A. Kumpf, (1972), Business Law, 6th ed., Cincinnati, Ohio; South-Western Publishing Co.

Ronny Hanitijo Soemitro, (1994), Metodologi Penelitian Hukum dan Jurimetri, cet. V, Jakarta; Ghalia Indonesia

Rudhi Prasetya, (1996), Kedudukan Mandiri Perseroan Terbatas, Bandung; Citra Aditya Bakti.
Sumantoro, (1986), Hukum Ekonomi, cet. I, Jakarta; Universitas Indonesia Press.

M. Yahya Harahap, (2016), Hukum Perseroan Terbatas, Jakarta; Sinar Grafika.

\section{Jurnal}

Arifin Kadarisman, (20-21 Juni 1989), Direksi sebagai Pekerja pada Perseroan Terbatas, Makalah, Jakarta; Konferensi tentang Direktur Perusahaan di Indonesia, Centre for Management Technology.

Victor Fungkong, (20-21 Juni 1989), Hukum Perusahaan dan Bentukbantuk Perusahaan, Makalah, Jakarta; Konferensi tentang Direktur Perusahaan di Indonesia, Centre for Management Technology.

\section{Websites}

Agus Riyanto, (_, Desember 2016), Ultra Vires dan Kewenangan Direksi, Diakses pada 19 Februari 2019, Dari Binus University Faculty of Humanity: http://businesslaw.binus.ac.id/2016/12/28/ultravires-dan-kewenangan-direksi/.

Rudi Agustian Hassim, (23 April 2018), Ultra Vires dan Intra Vires dalam Undang-Undang Perseroan Terbatas Indonesia, Diakses pada tanggal 19 Februari 2019, Dari Rah Law Firm: http://www.rahlawfirm.com/ultravires-dan-intra-vires/. 